\title{
A case study of aerosol scavenging in a biomass burning plume over eastern Canada during the 2011 BORTAS field experiment
}

\author{
J. E. Franklin ${ }^{1}$, J. R. Drummond ${ }^{1}$, D. Griffin ${ }^{2}$, J. R. Pierce ${ }^{3,1}$, D. L. Waugh $^{4}$, P. I. Palmer ${ }^{5}$, M. Parrington ${ }^{5, *}$, \\ J. D. Lee ${ }^{6}$, A. C. Lewis ${ }^{6}$, A. R. Rickard ${ }^{7, * *}$, J. W. Taylor ${ }^{8}$, J. D. Allan ${ }^{8,9}$, H. Coe ${ }^{8}$, K. A. Walker ${ }^{2}$, L. Chisholm ${ }^{4}$, \\ T. J. Duck ${ }^{1}$, J. T. Hopper ${ }^{1}$, Y. Blanchard ${ }^{10}$, M. D. Gibson ${ }^{11}$, K. R. Curry ${ }^{1}$, K. M. Sakamoto ${ }^{3,1}$, G. Lesins ${ }^{1}$, L. Dan ${ }^{2}$, \\ J. Kliever ${ }^{2}$, and A. Saha ${ }^{12}$ \\ ${ }^{1}$ Department of Physics and Atmospheric Science, Dalhousie University, Halifax, Nova Scotia, Canada \\ ${ }^{2}$ Department of Physics, University of Toronto, Toronto, Ontario, Canada \\ ${ }^{3}$ Department of Atmospheric Science, Colorado State University, Ft. Collins, CO, USA \\ ${ }^{4}$ Meteorological Service of Canada, Dartmouth, Nova Scotia, Canada \\ ${ }^{5}$ School of GeoSciences, University of Edinburgh, Edinburgh, UK \\ ${ }^{6}$ National Centre for Atmospheric Science (NCAS), Department of Chemistry, University of York, York, UK \\ ${ }^{7}$ National Centre for Atmospheric Science (NCAS), School of Chemistry, University of Leeds, Leeds, UK \\ ${ }^{8}$ Centre for Atmospheric Science, School of Earth, Atmospheric and Environmental Sciences, University of Manchester, \\ Manchester, UK \\ ${ }^{9}$ National Centre for Atmospheric Science, University of Manchester, Manchester, UK \\ ${ }^{10}$ Laboratoire Atmosphères, Milieux, Observations Spatiales, UPMC-UVSQ-CNRS, Paris, France \\ ${ }^{11}$ Department of Process Engineering and Applied Science, Dalhousie University, Halifax, Nova Scotia, Canada \\ ${ }^{12}$ CARTEL, Universite de Sherbrooke, Sherbrooke, Quebec, Canada \\ * now at: European Centre for Medium-Range Weather Forecasts, Reading, UK \\ ** now at: National Centre for Atmospheric Science (NCAS), Department of Chemistry, University of York, York, UK
}

Correspondence to: J. E. Franklin (j.franklin@dal.ca)

Received: 13 January 2014 - Published in Atmos. Chem. Phys. Discuss.: 6 February 2014

Revised: 4 June 2014 - Accepted: 18 June 2014 - Published: 21 August 2014

\begin{abstract}
We present measurements of a long-range smoke transport event recorded on 20-21 July 2011 over Halifax, Nova Scotia, Canada, during the Quantifying the impact of BOReal forest fires on Tropospheric oxidants over the Atlantic using Aircraft and Satellites (BORTAS-B) campaign. Ground-based Fourier transform spectrometers and photometers detected air masses associated with large wildland fires burning in eastern Manitoba and western Ontario.

We investigate a plume with high trace gas amounts but low amounts of particles that preceded and overlapped at the Halifax site with a second plume with high trace gas loadings and significant amounts of particulate material. We show that the first plume experienced a meteorological scavenging event, but the second plume had not been similarly scavenged. This points to the necessity to account carefully for the plume history when considering long-range transport
\end{abstract}

since simultaneous or near-simultaneous times of arrival are not necessarily indicative of either similar trajectories or meteorological history. We investigate the origin of the scavenged plume, and the possibility of an aerosol wet deposition event occurring in the plume $\sim 24 \mathrm{~h}$ prior to the measurements over Halifax. The region of lofting and scavenging is only monitored on an intermittent basis by the present observing network, and thus we must consider many different pieces of evidence in an effort to understand the early dynamics of the plume. Through this discussion we also demonstrate the value of having many simultaneous remote-sensing measurements in order to understand the physical and chemical behaviour of biomass burning plumes. 


\section{Introduction}

Wildland fires have burned an average of 2.3 million hectares of the Canadian boreal forest annually over the past $25 \mathrm{yr}$, with the majority of large fires being started by lightning strikes (data from the Canadian Wildland Fire Information System; http://cwfis.cfs.nrcan.gc.ca/). These biomass burning events are a significant source of carbonaceous aerosols and trace gases to the atmosphere. In addition to the local ecological effects, it has been demonstrated that plumes lofted into the free troposphere are capable of undergoing significant long-range transport (LRT) and chemical evolution (e.g. Crutzen and Andreae, 1990; Cooper et al., 2002; Derwent et al., 2004). The climatic implications of these perturbations to the troposphere are extremely sensitive to the characteristics of the LRT. As lofting of air via meso-scale convection often occurs during LRT, clouds may form and aerosol particles may be scavenged by cloud/rain drops and potentially removed from the atmosphere via wet deposition. These processes are therefore critical in determining aerosol lifetimes (e.g. Moteki et al., 2012; Seinfeld and Pandis, 2006). Many of these processes remain poorly constrained in atmospheric models (e.g. Croft et al., 2012; Browse et al., 2012), and further observations are necessary.

A number of recent field campaigns have looked at midto high-latitude wildfires and their impact on atmospheric composition. For example, the NASA Arctic Research of the Composition of the Troposphere from Aircraft and Satellites (ARCTAS) campaign in the summer of 2008 investigated the influence of biomass burning outflows on the Arctic environment (Jacob et al., 2010). An emphasis was placed on quantifying the chemical composition and near-field evolution of the fire plumes, as well as on better understanding their radiative impact on a regional scale. Transport pathways and the lofting efficiency of black carbon (BC) detected over Alaska during the ARCTAS campaign were investigated by Matsui et al. (2011), who found a discrepancy between BC released by wildfires in northern Russia and $\mathrm{BC}$ released by anthropogenic sources further to the south. Lofting of BC associated with the northern wildfires generally occurred isentropically at low relative humidity, while lofting of $\mathrm{BC}$ from more southern sources was often associated with rapid ascent and heavy precipitation (Matsui et al., 2011).

The Aerosol Radiative Forcing in East Asia (A-FORCE) campaign in the spring of 2009 specifically investigated the role of wet removal of BC in Asian outflow (Oshima et al., 2012). Precipitation was found to be the most important scavenger of BC from the atmosphere. However, previous studies (e.g. Andreae et al., 2004) have shown that precipitation washout can be inhibited by smoke thereby allowing aerosols to reach the upper troposphere. The interaction between the convective plumes from the fires, aerosols from the fires, and the local meteorology is complex and requires further study.

The Quantifying the impact of BOReal forest fires on Tropospheric oxidants over the Atlantic using Aircraft and Satel- lites (BORTAS) project was a multi-national campaign led by the University of Edinburgh and conducted over eastern Canada during the summers of 2010 and 2011. The overall goal of BORTAS was to investigate the connection between the composition and the distribution of biomass burning outflow, ozone production and loss within the outflow, and the resulting perturbation to atmospheric chemistry in the troposphere (Palmer et al., 2013). The primary data sets of the campaign were provided by the UK Facility for Airborne Atmospheric Measurements (FAAM) BAe-146 Atmospheric Research Aircraft (ARA) flying out of Halifax, Nova Scotia. These measurements were only available during the 2011 portion of the campaign (BORTAS-B; herein referred to as BORTAS). A series of 14 flights designed to sample biomass burning plumes of varying ages at a variety of altitudes were completed between 15 July and 3 August 2011. Flight paths were selected from the predictions of forecast models in order to maximize the probability of intercepting plumes. Specific flight paths are detailed in Palmer et al. (2013). A simultaneous ground-based campaign was undertaken to support the ARA measurements. In situ and remotesensing instruments were clustered at the Dalhousie Ground Station (DGS) located at Dalhousie University (Halifax, NS; $44.6^{\circ} \mathrm{N}, 63.6^{\circ} \mathrm{W} ; 65 \mathrm{~m}$ a.s.1.). The full list of DGS instruments is described in Palmer et al. (2013) and Gibson et al. (2013).

In this paper we present observational evidence of a biomass burning plume that experienced a period of precipitation scavenging during transport to the DGS. We begin by presenting a summary of the 2011 Canadian wildfire season. We follow this in Section 3 by describing the different instruments and methods used in this work. In Section 4 we present the time series of ground-station measurements and compare them with available aircraft and satellite data, as well as with transport model results. In Section 5 we present and discuss the observational evidence for precipitation along the plume trajectory. We conclude with a summary of our results.

\section{Overview of the 2011 wildfire season}

The wildfire season in the Canadian boreal forest runs from April to October with the majority of fires occurring from June to August (Canadian Forest Service; http://cfs.nrcan. gc.ca/). BORTAS measurement flights based out of Halifax were scheduled from 18 July to 31 July 2011 to coincide with this climatological peak.

A hot and unusually dry summer contributed to the province of Ontario recording a total of 1334 fires during the 2011 season with a total burned area of over 635000 ha, or roughly 5 times the $10 \mathrm{yr}$ average affected area (data from the Ontario Ministry of Natural Resources; http://www.mnr.gov. on.ca/). The Sioux Lookout 70 fire (SL70; $52.3^{\circ} \mathrm{N}, 90.7^{\circ} \mathrm{W}$ ) was the largest recorded Ontario fire in over $50 \mathrm{yr}$ with a total burn area of 141000 ha. Ignited by a lighting strike on 
14 July, SL70 burned for 6 days before being extinguished by rainfall. Smaller, yet still intense, wildland burning occurred in eastern Manitoba during the same period. Figure 1 shows the locations of fires catalogued by the NASA Fire Information for Resource Management System (FIRMS; Davies et al., 2009), using data from the MODerate Resolution Infrared Spectroradiometer (MODIS) instruments aboard the Aqua and Terra satellites (Giglio et al., 2003).

We will show that the differences in the local meteorology at each of these fire regions are a significant factor driving the differences in detections made downstream. A series of meso- to synoptic-scale disturbances tracked over Manitoba, Ontario, and southern Quebec during the campaign and provided the means for lofting biomass burning plumes out of the boundary layer. Beyond rapid uplift within thunderstorms, other possible mechanisms for initiating lofting include localized convective motions from the fires themselves, as well as transport along the warm conveyor belt of the synoptic lows (Cooper et al., 2002). Lofted plumes were efficiently transported toward the DGS via a strong mid-tropospheric flow driven by a major low-pressure system situated over the northern Quebec/northeastern Hudson Bay region, while lower level plumes remained under the influence of a slower westerly wind. A more detailed overview of the general meteorological conditions during the BORTAS mission can be found in Palmer et al. (2013).

\section{Measurements and models}

This paper will focus on the measurements made by the four remote-sensing instruments that were operating at DGS during the BORTAS campaign: two Fourier transform spectrometers (FTSs) providing solar absorption measurements of trace gases, a sun photometer providing aerosol optical depth during daylight hours, and a star photometer providing the same during clear nights.

\subsection{Fourier Transform Spectrometers}

\subsubsection{Dalhousie Atmospheric Observatory DA8}

The primary Dalhousie Atmospheric Observatory (DAO) instrument is a newly refurbished high-resolution DA8 FTS (DAO-DA8) manufactured by ABB (Bomem) and installed at Dalhousie University in 2010. The spectrometer is owned by the Canadian Space Agency, and the modifications to the electronics have been made at Dalhousie University. The heart of the DAO-DA8 is a Michelson Interferometer with a maximum optical path length of $250 \mathrm{~cm}$ providing an unapodized resolution of $0.004 \mathrm{~cm}^{-1}$. Alignment is maintained over the full optical path by monitoring the modulated signal of an internal HeNe laser. In accordance with procedures developed by the Network for the Detection of Atmospheric Composition Change (NDACC; information online at http://www.ndacc.org), solar absorption measurements are

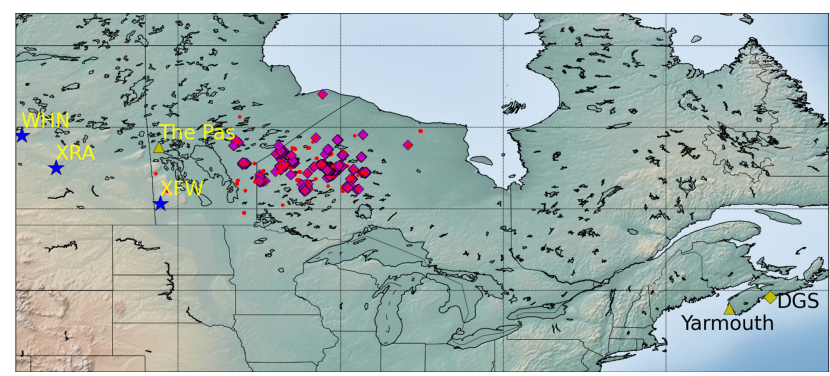

Figure 1. Map of eastern Canada showing all MODIS hotspots from 17 July to 20 July 2011 as detected by the Aqua and Terra satellites. Fires with radiative powers over $100 \mathrm{MW}$ are shown as diamonds. The location of the DGS is marked with a yellow diamond in the lower right, while radiosonde stations used in this study (The Pas, Yarmouth) are marked with yellow triangles. Radar facilities mentioned in the text (WHN, XRA, XFW) are marked with blue stars.

made through a series of six narrowband interference filters to optimize the signal to noise ratio. Every filter measurement consists of four to six co-added scans, enabling us to sample the entire spectrum from 750 to $4300 \mathrm{~cm}^{-1}$ (via all six filters) at full resolution every $55 \mathrm{~min}$.

A dedicated active-tracking heliostat was designed and built to support the DAO-DA8 spectrometer. The use of a camera in the tracker allows us to accurately monitor the position of the sun and make active feedback corrections, while a passive system of ephemeris calculations enables us to continue tracking in the event of a temporary loss of signal. This arrangement permits high tracking precision with a root mean square (rms) error of $\sim 10$ arcseconds.

\subsubsection{PARIS-IR}

The Portable Atmospheric Research Interferometric Spectrometer for the Infrared (PARIS-IR; Fu et al., 2007) was temporarily installed at the DGS during the BORTAS campaign. PARIS-IR was built by ABB (Bomem) as a groundbased adaption of the Atmospheric Chemistry Experiment FTS (ACE-FTS) aboard the SciSat satellite (Bernath et al., 2005). With a maximum optical path difference of $\pm 25 \mathrm{~cm}$, PARIS-IR measures the entire $750-4400 \mathrm{~cm}^{-1}$ spectral region with an unapodized resolution of $0.02 \mathrm{~cm}^{-1}$ every 7 min.

A second independent solar tracker of the same design as described above was installed at the DGS to provide PARISIR with a solar beam for its absorption measurements.

\subsubsection{Trace gas retrievals}

Columns of carbon monoxide $(\mathrm{CO})$, ethane $\left(\mathrm{C}_{2} \mathrm{H}_{6}\right)$, and nitrous oxide $\left(\mathrm{N}_{2} \mathrm{O}\right)$ were derived from measured solar spectra using an optimal estimation technique (Rodgers, 1976, 2000) as implemented by the retrieval software SFIT2 version 3.94c (Pougatchev et al., 1995, 1996). SFIT2 first calculates 
a spectrum using the High-Resolution Transmission Molecular Absorption Database (HITRAN) 2008 line list (Rothman et al., 2009) and a priori volume mixing ratio (VMR) profiles of trace gases. This synthetic spectrum is then compared and fitted to the observed spectrum by varying the vertical profile of the desired species and scaling the profiles of any interfering gas species. The retrieval is performed simultaneously over multiple short regions of the spectrum (referred to as microwindows) recommended by the NDACC community.

The two FTS systems retrieve trace gas profiles on vertical grids with different resolutions. PARIS-IR retrieves gas profiles on a 29-layer grid, while the higher spectral resolution of the DAO-DA8 allows us to retrieve profiles on a 48-layer grid. Thus, a proper comparison of the total gas column measurements between the two instruments requires smoothing the DAO-DA8 profiles using the PARIS-IR averaging kernels. This process is detailed in Griffin et al. (2013). Total and partial column values are calculated from the retrieved VMR profiles by integrating over the altitude range taking into account the density of the atmosphere at each layer.

With one exception, a priori VMR profiles for trace gases above Halifax were taken from 40 yr averages (19802020) of the Whole Atmosphere Climate Chemistry Model (WACCM V6; Eyring et al., 2007). Halifax is a marine site and the highly variable nature of water vapour above the DGS required the use of more accurate daily a priori water vapour VMR profiles. The lowest $20 \mathrm{~km}$ of the WACCM water vapour VMR profile was replaced with profiles calculated from radiosondes released every $12 \mathrm{~h}$ from Yarmouth, NS $\left(43.9^{\circ} \mathrm{N}, 66.1^{\circ} \mathrm{W} ; 9 \mathrm{~m}\right.$ a.s.1.). For the DAO-DA8, the inclusion of the radiosonde derived water vapour profiles removed a non-physical oscillation from the retrieved CO VMR profiles without significantly changing the total column. Although the temporal resolution of PARIS-IR greatly exceeds that of the DAO-DA8, the lower spectral resolution decreases the sensitivity of the instrument to CO above $\sim 5 \mathrm{~km}$, and only permits retrieval of total column abundances. Therefore, daily water vapour VMR profiles were not necessary in the PARIS-IR retrievals, and the mean WACCM a priori VMR was used. Pressure and temperature information were taken from the National Centers for Environmental Prediction (NCEP) each day and then interpolated onto the retrieval altitude grids.

DAO-DA8 retrievals of $\mathrm{C}_{2} \mathrm{H}_{6}$ produced $\sim 1.3$ degrees of freedom of signal (DOFS) and therefore only permit us to state a total column measurement. In contrast, $\mathrm{N}_{2} \mathrm{O}$ retrievals have $\sim 3.0$ DOFS, but the observed $\mathrm{N}_{2} \mathrm{O}$ enhancement is very modest; therefore we also only present total column measurements. CO is retrieved with $\sim 2.4$ DOFS, and the DAO-DA8 resolves the wings of the pressure broadened $\mathrm{CO}$ absorption lines sufficiently well to allow calculation of partial columns in addition to the total column value. Vertical limits of 0 to $4 \mathrm{~km}$ and 4 to $20 \mathrm{~km}$ were chosen to provide a full DOFS in each partial column. The contribution of CO above $20 \mathrm{~km}$ to the total column is less than $2 \%$.
Uncertainties in the derived columns were calculated in a manner similar to that described by Batchelor et al. (2009) and Griffin et al. (2013). Errors considered in our calculations include the smoothing error, measurement error, uncertainties in the HITRAN 2008 line parameters, and errors in the temperature profile.

\subsection{Sun and star photometers}

Dalhousie University has hosted an automated CIMEL Electronique 318A as part of the AEROCAN sun photometer network since June 2002. The AEROCAN network is a subset of the worldwide Aerosol Robotic Network (AERONET; Holben et al., 1998). The CIMEL sun photometer provides measurements of vertically integrated aerosol properties at a variety of optical wavelengths with a sampling resolution of about 3 min.

A star photometer operated by the University of Sherbrooke was temporarily installed at the DGS during the BORTAS campaign. Operating under a similar principle to the sun photometer, this instrument uses a telescope to monitor the light of known bright stars, thus allowing measurements of aerosol properties any cloud-free night (Herber, 2002).

The aerosol optical depth (AOD) at $500 \mathrm{~nm}$ is partitioned into a fine (roughly submicron) and coarse mode via a spectral deconvolution algorithm (SDA; O'Neill, 2003). As aerosols associated with the long-range transport of biomass burning plumes are expected to be on the submicron scale, we will only present the post-calibrated level 1.0 SDAderived fine-mode AOD in this paper.

\subsection{Dalhousie Raman Lidar}

The Dalhousie Raman Lidar (DRL) employs a Nd:YAG laser to produce $532 \mathrm{~nm}$ light at a pulse frequency of $20 \mathrm{~Hz}$. Vertical profiles of atmospheric scattering are derived from the returned signals at both the elastic scattering wavelength as well as at the nitrogen $\left(\mathrm{N}_{2}\right)$ Raman-shifted wavelength of $607 \mathrm{~nm}$. A complete description of the instrument, as well as a detailed discussion of the uncertainties in the measurements, is available in Bitar et al. (2010).

\subsection{BAe-146 aircraft instruments}

A multi-instrument payload was installed aboard the BAe146 ARA during the BORTAS campaign flights. A full listing of instruments can be found in Palmer et al. (2013). Of most interest to this paper are the Aerosol Mass Spectrometer (AMS) and CO monitor. The AMS had a temporal resolution of $30 \mathrm{~s}$ and provided measurements that include $\mathrm{NH}_{4}, \mathrm{SO}_{4}$, $\mathrm{NO}_{3}$, and organics (Jayne et al., 2000). The CO monitor operates via UV fluorescence with a temporal resolution of $1 \mathrm{~s}$, and a sensitivity of $1 \mathrm{ppb}$ (Gerbig et al., 1999; Taylor et al., 2014). 


\subsection{Numerical simulations}

The transport histories of plumes intercepted by the aircraft and the DGS remote-sensing instruments were first analysed using the HYbrid Single-Particle Lagrangian Integrated Trajectory (HYSPLIT) model (Draxler and Rolph, 2013; Rolph, 2013). Runs were initialized at the DGS and along the aircraft flight track and used NCEP Global Data Assimilation System (GDAS) reanalysis fields to model the transport to roughly locate the origins of the plumes. A more quantitative transport analysis was then performed using the Lagrangian Particle Dispersion Model FLEXPART (Stohl et al., 2005). Meteorology provided by the NCEP Global Forecast System (NCEP GFS) was used by FLEXPART to advect CO from biomass burning locations. Additional runs were completed using particles susceptible to removal via wet deposition.

\section{Results}

\subsection{Dalhousie Ground Station observations}

Total columns of $\mathrm{CO}, \mathrm{C}_{2} \mathrm{H}_{6}$, and $\mathrm{N}_{2} \mathrm{O}$ retrieved from the DGS spectrometers during the extended BORTAS ground campaign are shown in Fig. 2a-c. Biomass burning is a significant source of $\mathrm{CO}$ and $\mathrm{C}_{2} \mathrm{H}_{6}$, and a moderate source of $\mathrm{N}_{2} \mathrm{O}$ to the atmosphere. While $\mathrm{CO}$ and $\mathrm{C}_{2} \mathrm{H}_{6}$ are removed in a matter of months via reaction with $\mathrm{OH}$ radicals, $\mathrm{N}_{2} \mathrm{O}$ has been estimated to have a tropospheric residence time of over $100 \mathrm{yr}$, eventually being transported to the stratosphere where it is susceptible to photodissociation (Seinfeld and Pandis, 2006). Episodic correlated enhancements in these three species are considered to be evidence of biomass burning. PARIS-IR retrievals only detect significant enhancements in $\mathrm{CO}$ during the campaign period, and thus these are the only PARIS-IR measurements shown in Fig. 2. Total column CO values measured by DAO-DA8 agree with PARISIR retrievals within $4 \%$ after smoothing to a comparable vertical resolution (Griffin et al., 2013).

Fine-mode AOD data derived from sun and star photometer measurements during the campaign are shown in Fig. 2d. As demonstrated in Fig. 7 of Griffin et al. (2013), the finemode AOD is generally positively correlated with total column CO throughout the campaign. However, not all measurements of specific air masses follow this trend, and it is one of these exceptions that is investigated in this paper.

The strongest $\mathrm{CO}$ signal seen in Fig. 2 is associated with a plume that arrived in the afternoon of 20 July 2011. Solar tracking instruments at the DGS intercepted the plume to the southwest before it was detected by zenith-pointing instruments (including the DRL). Measurements of CO and AOD during this event are expanded in Fig. 3a and b. The total column of $\mathrm{CO}$ begins to rise at 17:30 UTC from a local morning value of $(2.0 \pm 0.1) \times 10^{18}$ molec cm$^{-2}$ and reaches $(2.9 \pm 0.1) \times 10^{18}$ molec $\mathrm{cm}^{-2}$ by 21:20 UTC (Fig. 3a). The

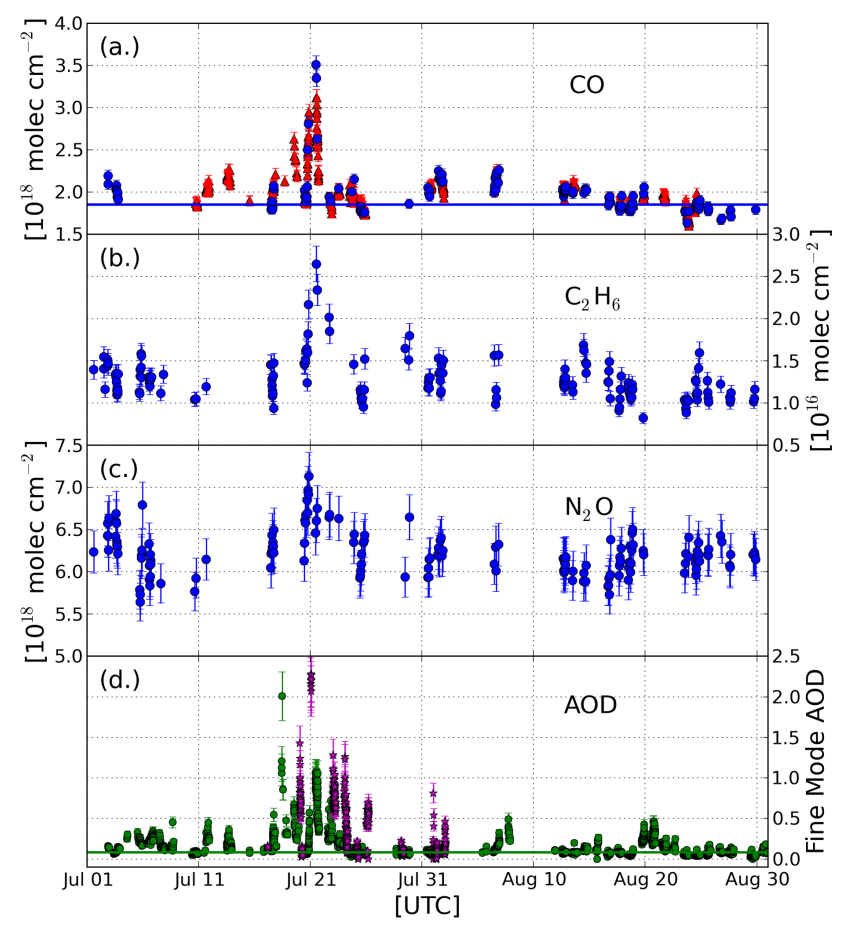

Figure 2. DGS remote-sensing measurements observed during the extended BORTAS campaign. (a) Total retrieved column of $\mathrm{CO}$ as measured by the DAO-DA8 (blue circles) and PARIS-IR (red triangles). Typical background column of CO above the DGS in the summer is shown by the horizontal blue line. (b and $\mathbf{c}$ ) Total column of $\mathrm{C}_{2} \mathrm{H}_{6}$ and $\mathrm{N}_{2} \mathrm{O}$ derived from DAO-DA8. (d) Fine-mode AOD derived from the CIMEL sun photometer (green circles), and star photometer (magenta stars). Background level of fine-mode AOD at the DGS is shown by the horizontal green line.

enhancement appears to have continued throughout the night as a maximum value of $(3.5 \pm 0.1) \times 10^{18}$ molec cm $^{-2}$ was measured on the morning of 21 July. Total column values then declined throughout the day, but the sun was obscured by clouds from 18:00 UTC to sunset ( $\sim 23: 50$ UTC) so there are no measurements in that period.

Figure $3 b$ shows the derived fine-mode AOD from the CIMEL sun photometer and star photometer throughout the event. The arrival of the plume is marked by a sudden increase in both the coarse- and fine-mode AOD around 20:30 UTC on 20 July. From a typical background value of 0.05 , the fine-mode AOD climbed to 0.6 in less than $2 \mathrm{~h}$ before the sun set and continued to rise into the night when the star photometer measured a peak value of 2.3 at 01:30 UTC. The extreme optical depth of this event interfered with the star photometer's ability to properly focus on stars, and therefore permitted only a handful of star photometer measurements during the night. After sunrise on 21 July $(\sim 08: 50$ UTC) the sun photometer measured a fine-mode AOD value of 1.0 that then declined throughout the day. Coarse-mode AOD (not shown) associated with clouds begins to interfere with measurements by 18:00 UTC. 

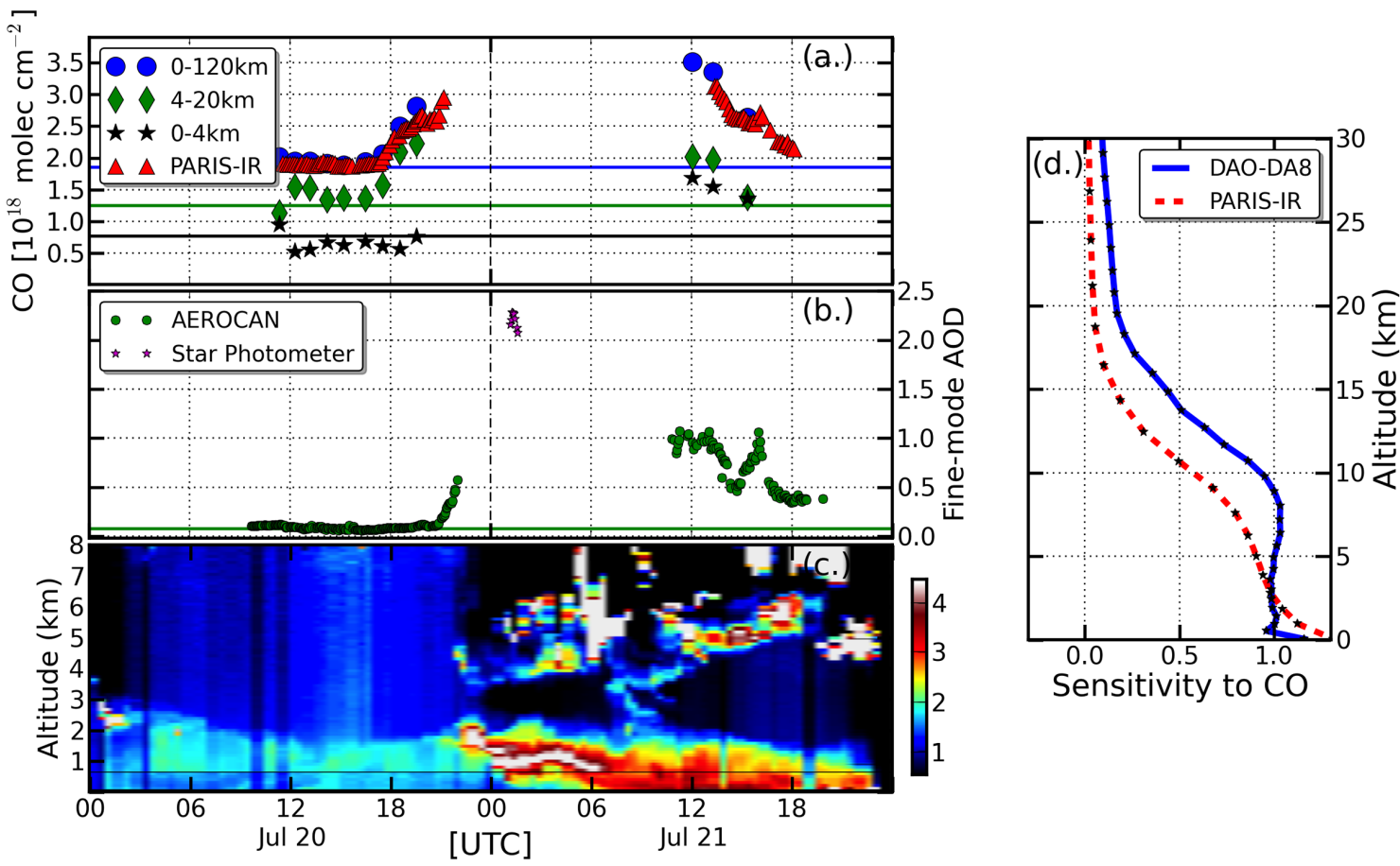

Figure 3. DGS observations of the 20-21 July biomass burning event. (a) Retrieved total and partial columns of CO (in molec $\mathrm{cm}^{-2}$ ). Horizontal lines represent typical background total and partial columns of CO at DGS (0-4 km lowest, 4-20 km middle, total column upper). (b) Fine-mode AOD as measured by the sun and star photometers. The horizontal line represents the typical background fine-mode AOD at DGS. (c) DRL attenuated backscatter ratio showing vertical distribution of aerosols above DGS. (d) Sensitivity, as a function of altitude, of the PARIS-IR and DAO-DA8 retrievals of $\mathrm{CO}$ to the true profile rather than the a priori profile.

Of particular interest is the onset of the event. The higher spectral resolution of the DAO-DA8 enables us to retrieve partial columns of $\mathrm{CO}$ from our measurements. In addition to the total CO column from 0 to $120 \mathrm{~km}$, Fig. 3a shows retrieved partial CO columns from 0 to $4 \mathrm{~km}$, and from 4 to $20 \mathrm{~km}$. Although the second partial column extends to $20 \mathrm{~km}$, typical July tropopause heights above Halifax are closer to $12 \mathrm{~km}$, resulting in a sensitivity to $\mathrm{CO}$ that is highest between 4 and $12 \mathrm{~km}$. Lines representing typical background partial and total column values are also shown in Fig. 3a. There is some evidence of an enhancement of $\mathrm{CO}$ in the mid-upper troposphere column starting at 13:00 UTC on 20 July, although this is made uncertain by an absence of earlier measurements. Then, at 17:30 UTC, a clear signal of a significant mid-upper troposphere enhancement begins that is not observed in the lower column. This is in contrast to 21 July when we see strong enhancements in both the lower and upper tropospheric partial columns.

These 0 to $4 \mathrm{~km}$ partial $\mathrm{CO}$ column observations are in agreement with the vertically resolved DRL attenuated backscatter ratio shown in Fig. 3c. The backscatter ratio is derived by comparing the measured lidar signal against a modelled aerosol-free atmosphere. No significant aerosol enhancement is seen on 20 July until around 22:00 UTC, at which point a strong signal appears and persists throughout
21 July. The DRL measurement ends at 22:00 UTC on 21 July when fog and rain moved over the DGS.

There is clear evidence for an enhancement of $\mathrm{CO}$ in the upper levels of the troposphere on 20 July $\sim 3 \mathrm{~h}$ ahead of the fine-mode AOD increase, and some indications of a smaller increase $\sim 9 \mathrm{~h}$ ahead. These observations suggest the presence of a high-trace gas/low-particulate plume ahead of an additional plume with high levels of both particles and gases. One possible explanation for this observation involves a single plume that underwent a change in composition with time. Alternatively, these observations reflect the overlapping of two air masses with different histories. We will distinguish between these possibilities using satellite and aircraft observations supplemented by atmospheric transport modelling.

\subsection{Satellite and aircraft observations}

It is important to interpret our column measurements from the DGS within the context of the larger regional picture. A variety of different satellite-derived atmospheric products are available with near-daily global coverage. Images gathered on 20 July by the MODIS instrument aboard the NASA Aqua platform (passing over the DGS at 17:50 UTC) show a region of low AOD over Nova Scotia with significantly higher AODs to both the east and west of the region (Fig. 4). At the same time, the Atmospheric 
Infrared Sounder (AIRS; McMillan et al., 2008), also aboard Aqua, measured an enhanced total-column $\mathrm{CO}$ value of $(2.6 \pm 0.2) \times 10^{18}$ molec $\mathrm{cm}^{-2}$ over Halifax in agreement with the DAO-DA 8 measurements. CO columns as high as $4.0 \times 10^{18}$ molec $\mathrm{cm}^{-2}$ are seen approaching from the west. While the satellite measurements broadly support the DGS observations, they do not provide sufficient vertical information.

The BAe-146 ARA in situ measurements gathered $800 \mathrm{~km}$ upwind of the DGS during flight no. B622 on 20 July show that there were indeed two distinct plumes (in terms of gas and aerosol concentrations) moving toward Halifax. While flying west from northern New Brunswick, the ARA performed a sawtooth pattern of profile ascents/descents in advance of a cold front associated with a surface low. Figure 5a shows the concentration of organic aerosols $\left(\mu \mathrm{g} \mathrm{m}^{-3}\right.$, as measured by the onboard AMS) plotted against $\mathrm{CO}$ (ppbv) for an ascent that began at 16:11 UTC at a position of $47.7^{\circ} \mathrm{N}, 70.0^{\circ} \mathrm{W}$, at an altitude of $1.9 \mathrm{~km}$ and ended at $47.8^{\circ} \mathrm{N}, 71.5^{\circ} \mathrm{W}$, at an altitude of $7.5 \mathrm{~km}$. Two distinct plumes of elevated $\mathrm{CO}$ are clearly visible in the data: a low altitude layer between 3 and $4 \mathrm{~km}$, and a thinner layer above at an altitude of $6.5 \mathrm{~km}$. There is a clear relationship between $\mathrm{CO}$ and organics in the lower plume, while the upper plume of CO shows little enhancement in organic material. The aircraft then descended to a position of $47.8^{\circ} \mathrm{N}, 72.8^{\circ} \mathrm{W}$, at an altitude of $1.9 \mathrm{~km}$ and measured a similar pattern of two vertically distinct plumes of $\mathrm{CO}$ with drastically different organic aerosol loadings (Fig. 5b). The full track of flight no. B622 is shown in Fig. 6.

The contrast of elevated $\mathrm{CO}$ concentrations and elevated organic aerosol mass in the lower plume vs. elevated CO concentrations and low organic aerosol mass in the upper plume supports the theory that the two plumes followed different paths with different histories, and that the upper plume may have experienced a lofting event coupled with removal of the aerosol mass. The ARA measurements are geographically and temporarily separated from the DGS observations, yet reflect the regional presence of vertically separated biomass burning plumes. While we use the ARA flight no. B622 measurements simply to support our theory of two vertically separated plumes, Taylor et al. (2014) perform a full analysis of aerosol properties measured in the different plumes aboard the ARA.

\subsection{Trajectory analysis}

The HYSPLIT dispersion model was used to locate a probable origin of the two plumes intercepted by the DGS remote-sensing instruments. The backwards trajectory for the lower particle-rich plume was initialized at 00:00 UTC 21 July 2011 with an even distribution of particles between 0.5 and $1.5 \mathrm{~km}$ to match the observations made by the DRL (Fig. 3c). The backwards trajectory of the upper-troposphere particle-poor plume was more sensitive to starting times, so
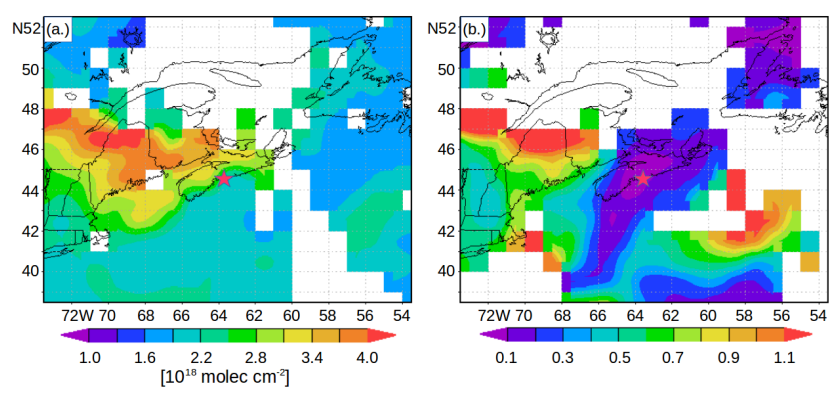

Figure 4. Satellite observations made during the 17:50 UTC ascending pass of Aqua over the DGS on 20 July 2011. (a) Total column CO measured by the AIRS instrument (Level 3 daily standard physical retrieval V005) showing a large enhancement approaching the DGS (marked by star near centre of plot). (b) Simultaneous $550 \mathrm{~nm}$ aerosol optical depth as measured by the MODIS instrument showing a region of low-aerosol loading above the DGS. White regions indicate interference from clouds.

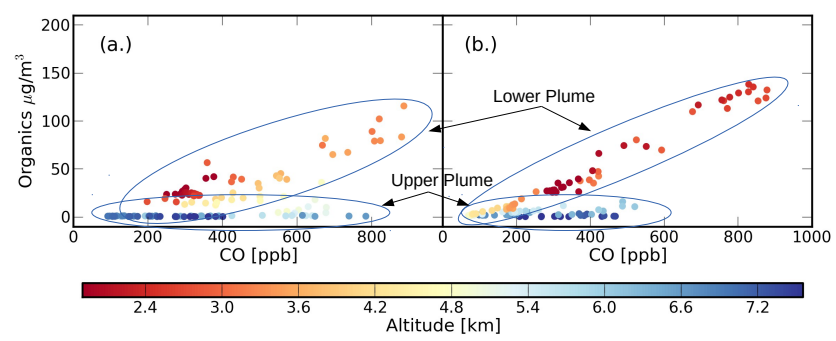

Figure 5. In situ measurements of organic particulate mass plotted against $\mathrm{CO}$ as measured by instruments aboard the BAe-146 ARA during (a) an ascent, and (b) the subsequent descent on 20 July 2011 during flight no. 622. Exact locations of the profiles are given in the text and plotted in Fig. 6. Both profiles revealed the presence of two vertically separated plumes of $\mathrm{CO}$, and that the upper plume contained little or no organics.

a series of runs were performed with releases ranging from 14:00 to 19:00 UTC. Although the best timing with DAODA8 measurements did not show strong vertical motions, backwards trajectories with small changes in start time exhibited rapid lofting of the air mass $\sim 24 \mathrm{~h}$ before detection at the DGS. Considering the coarse grid of the NCEP GDAS meteorology used to advect the particles, we believe that 15:00 UTC on 20 July is an acceptable initialization time for modelling the upper-troposphere plume. An even distribution of particles between 7.0 and $9.0 \mathrm{~km}$ was used to match the centre of the CO sensitivity of the DAO-DA8's upper partial column. Both backwards trajectories were started above the DGS, and run for $84 \mathrm{~h}$. No deposition or chemical evolution was considered in these models.

The HYSPLIT model shows that the majority of the lower plume remained in the lowest $3 \mathrm{~km}$ of the atmosphere throughout the modelled time, and the footprint at $-84 \mathrm{~h}$ covers the region of fires in northwestern Ontario (Fig. 7). This is in contrast to the upper plume that is shown to 


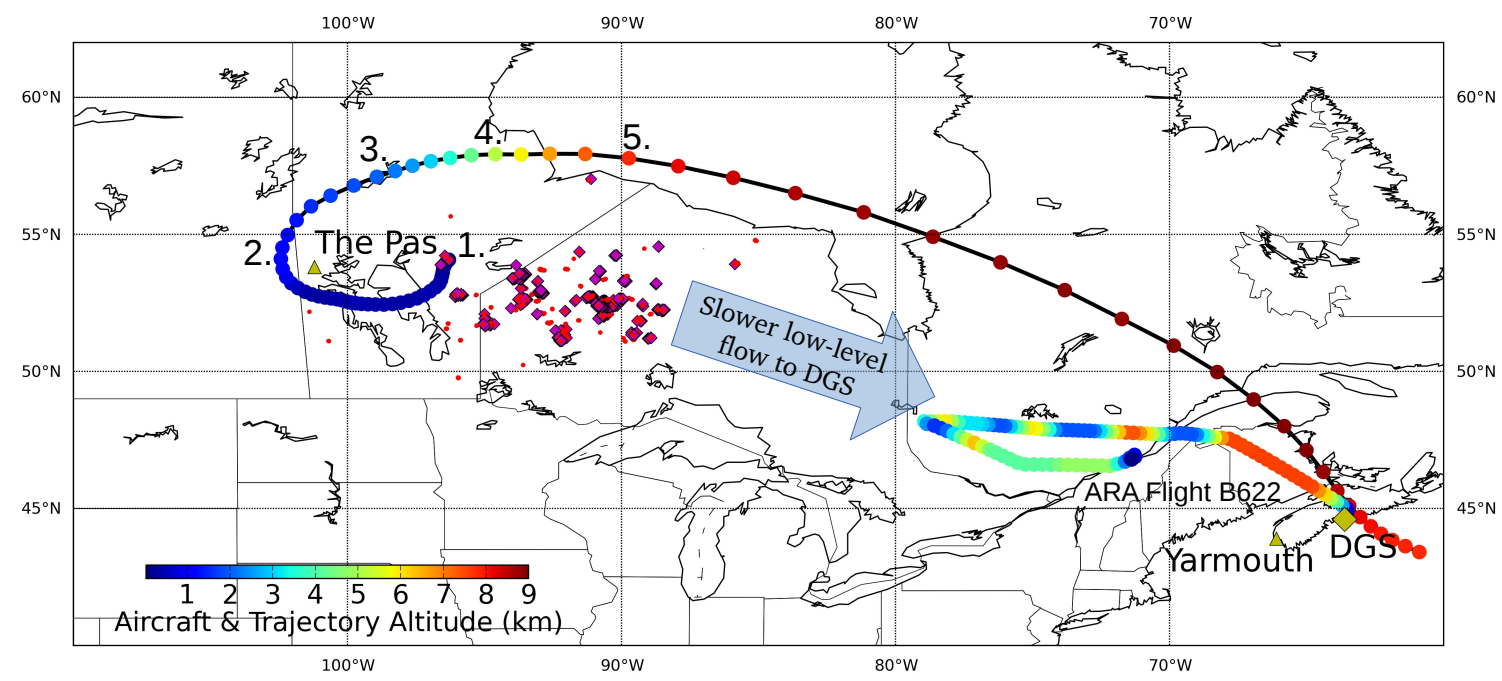

Figure 6. Representative upper plume trajectory from the HYSPLIT model. Particles were released at 18:00 UTC on 17 July 2011 from $54.07^{\circ} \mathrm{N}, 96.30^{\circ} \mathrm{W}$. Also shown is the flight path of the ARA during flight B622 on 20 July 2011. Plume and aircraft altitudes are reflected by the marker colours. See text for details of plume transport at numbered positions.

have approached from southern Hudson Bay after undergoing a period of intense lofting. This lofting is clearly visible in the HYSPLIT dispersion model time step shown in Fig. 8. The resulting footprint from the upper plume suggests that there was little or no contribution from the main Ontario fires, but a possible contribution from the region of Lake Winnipeg in Manitoba on 17 July.

Possible fires in this area were identified using MODIS fire counts from NASA FIRMS. Mid-July conditions in eastern Manitoba were hot and dry with a ridge of high pressure settled over the region. On 16 July, the MODIS instruments aboard Aqua and Terra first detected fires in the region northeast of Lake Winnipeg. Many of these fires significantly expanded in both size and intensity over the next $24 \mathrm{~h}$, and the largest continued to burn until being extinguished by rainfall on 19 July. This general region (position 1; Fig. 6) was used to initialize a more detailed FLEXPART forward trajectory. Both HYSPLIT and FLEXPART indicate that the plume remained within the boundary layer for almost $24 \mathrm{~h}$ where it was influenced by easterly winds which carried it away from the Ontario fires and toward the Saskatchewan border. Figure 6 shows a single HYSPLIT trajectory that is representative of the full FLEXPART results. It is important to recognize that these models are not well suited to accurately describe transport within the boundary layer. However, there is a general agreement between the models that the air mass west of The Pas, Manitoba $\left(53.8^{\circ} \mathrm{N}, 101.2^{\circ} \mathrm{W}\right)$, underwent $\sim 18 \mathrm{~h}$ of moderate to strong vertical ascent.

FLEXPART results suggest that dispersion by the vertical wind shear during the dynamic lofting between positions 3 and 5 in Fig. 6 significantly lowered the $\mathrm{CO}$ and aerosol concentrations within the plume. Additional FLEXPART runs using particles susceptible to removal via wet deposition

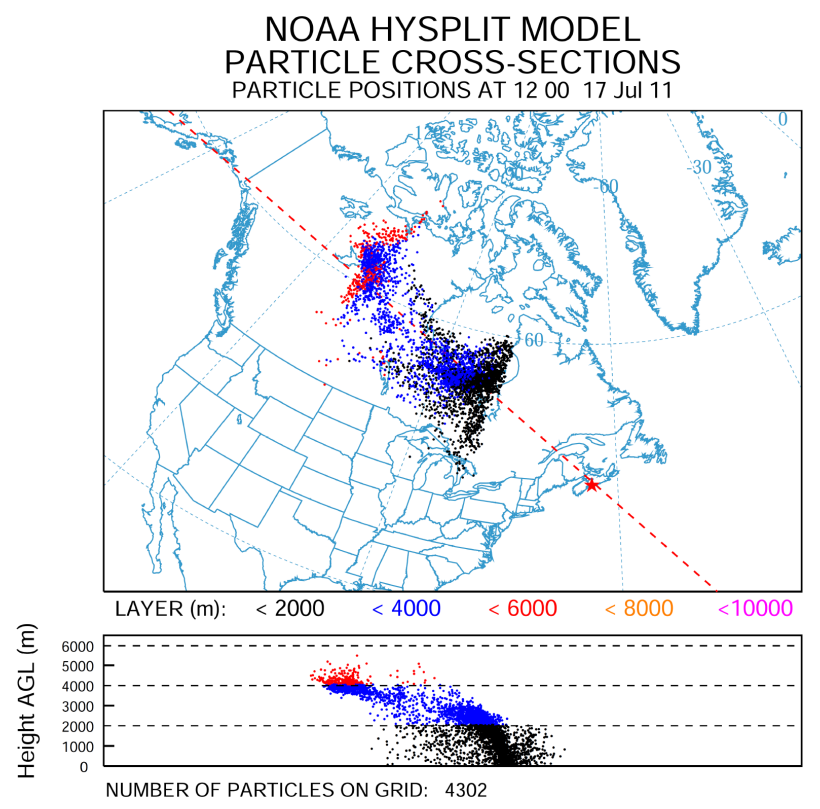

Figure 7. HYSPLIT dispersion model showing location contributions to the lower plume of trace gas and aerosols observed at 00:00 UTC from the DGS on 21 July 2011. Particles were initialized between 0.5 and $1.5 \mathrm{~km}$ above the DGS (marked by red star) and advected back by $84 \mathrm{~h}$. A significant overlap is observed between the model footprint and regions of wildland fires in western Ontario (see Fig. 1). The lower panel shows the vertical distribution of particles along the red dashed line in the upper panel with the majority of the particles still in the lowest $4 \mathrm{~km}$ of the atmosphere.

show a further loss in particle concentrations during the lofting phase. The now particle-poor plume eventually reached $8 \mathrm{~km}$ where it was quickly transported toward Halifax via 


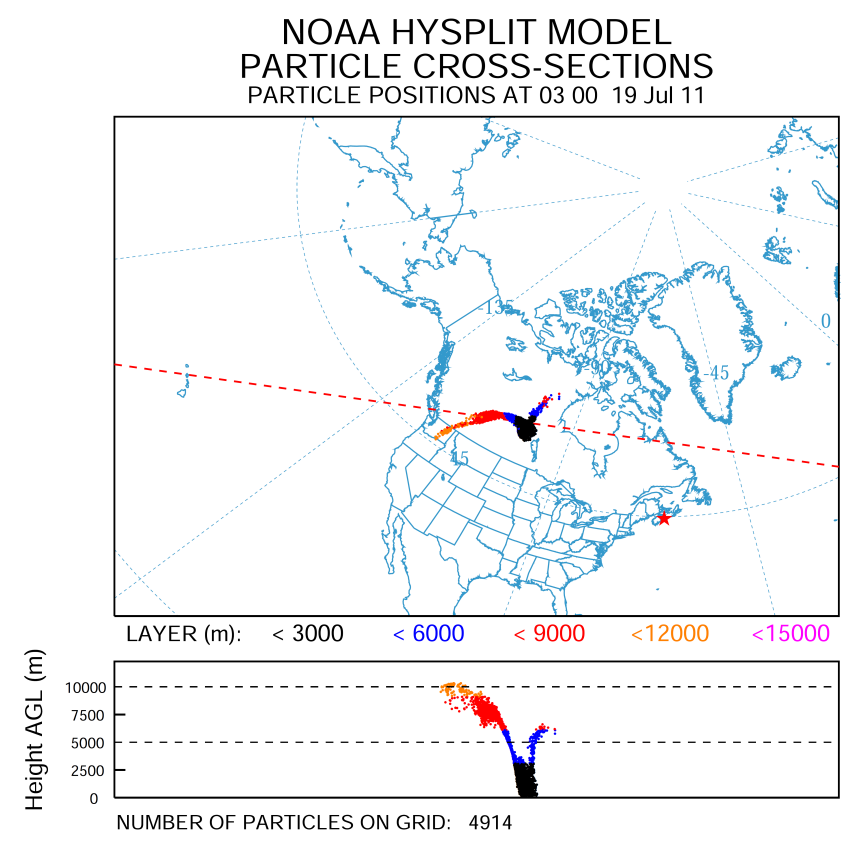

Figure 8. HYSPLIT dispersion model showing location contributions to the upper plume of trace gas observed at 15:00 UTC from the DGS on 20 July 2011. Particles were initialized between 7.0 and $9.0 \mathrm{~km}$ above the DGS (marked by red star) and advected back by $36 \mathrm{~h}$. Contributions from below $4.0 \mathrm{~km}(\sim 70 \%$ of particles released) are concentrated at the border of Manitoba and Saskatchewan in the region where reports of smoke were observed. This time step corresponds to position 2 in Fig. 6. The lower panel shows the vertical distribution of particles along the red dashed line in the upper panel.

a strong west-northwest flow driven by an upper-level low pressure system situated over northeast Hudson Bay.

\section{Evidence of precipitation}

The HYSPLIT model tracks rainfall along trajectories using information from the NCEP GDAS reanalysis and shows that the plume of interest passed through a broad region of precipitation in northern Manitoba with rainfall rates of 5 to $7 \mathrm{~mm} \mathrm{~h}^{-1}$ (Fig. 9). A similar analysis shows that the lower particle-rich plume did not encounter any precipitation during transport to the DGS. Very few ground station measurements exist in northern Manitoba to confirm this precipitation reanalysis, and the region is beyond the range of the nearest radar station. However, a number of pieces of information combine to provide evidence for this lofting event.

First, surface analysis charts of this region provided by Environment Canada's Prairie and Arctic Storm Prediction Centre (Winnipeg, Manitoba Office) show the passage of a small area of low pressure early on 19 July. Station pressure at The Pas, Manitoba, began falling around 18:00 UTC on 18 July under mostly cloudy skies. The sounding released from

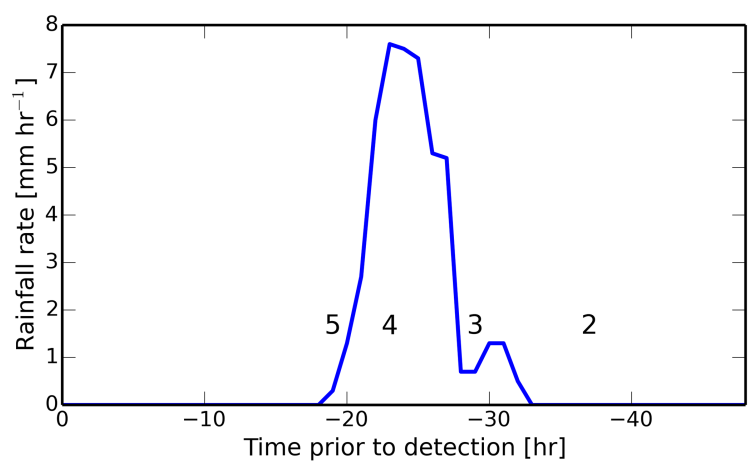

Figure 9. Precipitation rates along the HYSPLIT trajectory shown in Fig. 6 for the upper, potentially scavenged, air mass. The rainfall information was derived using the NCEP GDAS reanalysis. Time on the horizontal axis is measured in hours prior to detection of the air mass at the DGS. Numbers correspond to HYSPLIT positions marked in Fig. 6. The same analysis applied to the trajectories for the lower particle-rich plume does not show any significant precipitation along the path (not shown).

The Pas at 00:00 UTC 19 July shows an atmosphere that was conditionally unstable above $2 \mathrm{~km}$. The Pas weather observations recorded a temperature of $26^{\circ} \mathrm{C}$ and reported smoke that lowered the visibility below $10 \mathrm{~km}$. Thus, the conditions were in place for the initial lofting of the biomass burning plume.

Second, although radar data are unavailable along the plume trajectory, the radar stations farther to the west in Saskatchewan and Alberta (see Fig. 1) detected the initial precipitation from a forming mesoscale convective system (historical radar data taken from National Climate Data and Information Archive, Canada). At 00:00 UTC on 19 July a line of thunderstorms, oriented north-south, formed along an advancing cold front south of Edmonton, $\mathrm{AB}$, and bloomed in size and intensity while travelling east. The system crossed the western border of Saskatchewan around 04:00 UTC 19 July.

Finally, high numbers of lightning strikes associated with this system were detected by the Canadian Lightning Detection Network (Burrows et al., 2002). Thunderstorms were observed at The Pas between 07:00 and 09:00 UTC, and a total rainfall of $11.4 \mathrm{~mm}$ was recorded during this event. Other regional stations reported rainfalls between 10 and $20 \mathrm{~mm}$, and a number of significant weather events were noted in the region including hail with diameters in excess of $6 \mathrm{~cm}$.

Thus, despite the remote location with its sparse observing network, it is clear that a convective event with moderate to heavy rainfall transited northern Manitoba early on 19 July. The correlation between this rainfall and the trajectory analysis described above supports the theory that some biomass burning plumes in eastern Manitoba experienced a period of precipitation scavenging while being lofted to the upper troposphere. 


\section{Conclusions}

We provided ground-based remote sensing of trace gases and aerosols in support of the BORTAS mission during the summer of 2011. Halifax, NS, was shown to be an acceptable location for monitoring the outflow of several biomass burning plumes during the summer of 2011. The clustering of remotesensing instruments at the DGS enabled us to successfully identify a higher altitude plume of enhanced trace gases with low amounts of particulate matter that arrived prior to and overlapped with a lower altitude plume containing significant amounts of particles.

The presence of this low-particulate concentration plume was verified by aircraft and satellite measurements; however, ground-based remote-sensing measurements were sufficient to detect this event. We demonstrated via transport models and local meteorological data that this plume originated from fires in Manitoba and very likely experienced a lofting event associated with precipitation scavenging of the aerosol mass. We also show that plumes detected at Halifax from fires in Ontario were not lofted by this system and retained a significant portion of their aerosol mass during transport. Thus, what began as similar plumes of biomass burning emissions evolved under the influences of local meteorology into plumes with dramatically different characteristics.

This work shows that, in order to adequately model the atmospheric impact of biomass burning events, it is critically important to understand the meteorological conditions along the trajectory and particularly in places where the plume changes altitude. Future efforts to model the climatic importance of biomass burning plumes will benefit from an enhanced investment in the meteorological observing network of the Canadian boreal forest.

Acknowledgements. Funding for the DGS measurements has been provided by NSERC, the Canadian Space Agency (CSA), and Environment Canada (EC). BORTAS was supported by the Natural Environment Research Council (NERC) under grant number NE/F017391/1. P. I. Palmer also acknowledges support from the Leverhulme Trust and the Nuffield Foundation. Airborne data were obtained using the BAe-146-301 Atmospheric Research Aircraft (ARA) operated by Directflight Ltd and managed by the Facility for Airborne Atmospheric Measurements, which is a joint entity of the NERC and the UK Meteorological Office. Satellite data were obtained from the Giovanni online data system, developed and maintained by the NASA GES DISC. We would also like to acknowledge the support provided by the AEROCAN network (a subnetwork of AERONET) with particular thanks to Ihab Abboud of Environment Canada and Norm O'Neill and Jim Freemantle of the Université de Sherbrooke.

Edited by: S. Matthiesen

\section{References}

Andreae, M. O., Rosenfeld, D., Artaxo, P., Costa, A. A., Frank, G. P., Longo, K. M., and Silva-Dias, M. A. F.: Smoking rain clouds over the Amazon, Science, 303, 1337-1342, doi:10.1126/science.1092779, 2004.

Batchelor, R. L., Strong, K., Lindenmaier, R., Mittermeier, R. L., Fast, H., Drummond, J. R., and Fogal, P. F.: A new Bruker IFS 125HR FTIR spectrometer for the polar environment atmospheric research laboratory at Eureka, Nunavut, Canada: measurements and comparison with the existing Bomem DA8 spectrometer, J. Atmos. Ocean. Tech., 26, 1328-1340, doi:10.1175/2009JTECHA1215.1, 2009.

Bernath, P. F., McElroy, C. T., Abrams, M. C., Boone, C. D., Butler, M., Camy-Peyret, C., Carleer, M., Clerbaux, C., Coheur, P.F., Colin, R., DeCola, P., DeMazière, M., Drummond, J. R., Dufour, D., Evans, W. F. J., Fast, H., Fussen, D., Gilbert, K., Jennings, D. E., Llewellyn, E. J., Lowe, R. P., Mahieu, E., McConnell, J. C., McHugh, M., McLeod, S. D., Michaud, R., Midwinter, C., Nassar, R., Nichitiu, F., Nowlan, C., Rinsland, C. P., Rochon, Y. J., Rowlands, N., Semeniuk, K., Simon, P., Skelton, R., Sloan, J. J., Soucy, M.-A., Strong, K., Tremblay, P., Turnbull, D., Walker, K. A., Walkty, I., Wardle, D. A., Wehrle, V., Zander, R., and Zou, J.: Atmospheric Chemistry Experiment (ACE): mission overview, Geophys. Res. Lett., 32, L15S01, doi:10.1029/2005GL022386, 2005.

Bitar, L., Duck, T. J., Kristiansen, N. I., Stohl, A., and Beauchamp, S.: Lidar observations of Kasatochi volcano aerosols in the troposphere and stratosphere, J. Geophys. Res., 115, D00L13, doi:10.1029/2009JD013650, 2010.

Browse, J., Carslaw, K. S., Arnold, S. R., Pringle, K., and Boucher, O.: The scavenging processes controlling the seasonal cycle in Arctic sulphate and black carbon aerosol, Atmos. Chem. Phys., 12, 6775-6798, doi:10.5194/acp-12-6775-2012, 2012.

Burrows, W. R., King, P., Lewis, P. J., Kochtubajda, B., Snyder, B., and Turcotte, V.: Lightning occurrence patterns over Canada and adjacent United States from lightning detection network observations, Atmos. Ocean, 40, 59-80, doi:10.3137/ao.400104, 2002.

Cooper, O. R., Moody, J. L., Parrish, D. D., Trainer, M., Holloway, J. S., Hubler, G., Fehsenfeld, F. C., and Stohl, A.: Trace gas composition of midlatitude cyclones over the western North Atlantic Ocean: a seasonal comparison of $\mathrm{O}_{3}$ and CO, J. Geophys. Res., 107, 4057, doi:10.1029/2001JD000902, 2002.

Croft, B., Pierce, J. R., Martin, R. V., Hoose, C., and Lohmann, U.: Uncertainty associated with convective wet removal of entrained aerosols in a global climate model, Atmos. Chem. Phys., 12, 10725-10748, doi:10.5194/acp-12-10725-2012, 2012.

Crutzen, P. J. and Andreae, M. O.: Biomass burning in the tropics: impact on atmospheric chemistry and biogeochemical cycles, Science, 250, 1669-1678, doi:10.1126/science.250.4988.1669, 1990.

Davies, D., Ilavajhala, S., and Justice, C.: Fire information for resource management system: archiving and distributing MODIS active fire data, IEEE T. Geosci. Remote, 47, 72-79, doi:10.1109/TGRS.2008.2002076, 2009.

Derwent, R., Stevenson, D., Collins, W., and Johnson, C.: Intercontinental transport and the origins of the ozone observed at surface sites in Europe, Atmos. Environ., 38, 1891-1901, doi:10.1016/j.atmosenv.2004.01.008, 2004. 
Draxler, R. and Rolph, G.: HYSPLIT (HYbrid Single-Particle Lagrangian Integrated Trajectory) Model access via NOAA ARL READY Website http://ready.arl.noaa.gov/HYSPLIT.php (last access: 9 January 2014), NOAA Air Resources Laboratory, Silver Spring, MD, 2013.

Eyring, V., Waugh, D. W., Bodeker, G. E., Cordero, E., Akiyoshi, H., Austin, J., Beagley, S. R., Boville, B. a., Braesicke, P., Brühl, C., Butchart, N., Chipperfield, M. P., Dameris, M., Deckert, R., Deushi, M., Frith, S. M., Garcia, R. R., Gettelman, a., Giorgetta, M. a., Kinnison, D. E., Mancini, E., Manzini, E., Marsh, D. R., Matthes, S., Nagashima, T., Newman, P. a., Nielsen, J. E., Pawson, S., Pitari, G., Plummer, D. a., Rozanov, E., Schraner, M., Scinocca, J. F., Semeniuk, K., Shepherd, T. G., Shibata, K., Steil, B., Stolarski, R. S., Tian, W., and Yoshiki, M.: Multimodel projections of stratospheric ozone in the 21st century, J. Geophys. Res., 112, D16303, doi:10.1029/2006JD008332, 2007.

Fu, D., Walker, K. A., Sung, K., Boone, C. D., Soucy, M.-A., and Bernath, P. F.: The portable Atmospheric Research interferometric spectrometer for the infrared, PARIS-IR, J. Quant. Spectrosc. Ra., 103, 362-370, doi:10.1016/j.jqsrt.2006.05.006, 2007.

Gerbig, C., Schmitgen, S., Kley, D., Volz-Thomas, A., Dewey, K., and Haaks, D.: An improved fast-response vacuum-UV resonance fluorescence CO instrument, J. Geophys. Res., 104, 1699, doi:10.1029/1998JD100031, 1999.

Gibson, M. D., Pierce, J. R., Waugh, D., Kuchta, J. S., Chisholm, L., Duck, T. J., Hopper, J. T., Beauchamp, S., King, G. H., Franklin, J. E., Leaitch, W. R., Wheeler, A. J., Li, Z., Gagnon, G. A., and Palmer, P. I.: Identifying the sources driving observed $\mathrm{PM}_{2.5}$ temporal variability over Halifax, Nova Scotia, during BORTAS-B, Atmos. Chem. Phys., 13, 7199-7213, doi:10.5194/acp-13-7199-2013, 2013.

Giglio, L., Descloitres, J., Justice, C. O., and Kaufman, Y. J.: An enhanced contextual fire detection algorithm for MODIS, Remote Sens. Environ., 87, 273-282, 2003.

Griffin, D., Walker, K. A., Franklin, J. E., Parrington, M., Whaley, C., Hopper, J., Drummond, J. R., Palmer, P. I., Strong, K., Duck, T. J., Abboud, I., Bernath, P. F., Clerbaux, C., Coheur, P.F., Curry, K. R., Dan, L., Hyer, E., Kliever, J., Lesins, G., Maurice, M., Saha, A., Tereszchuk, K., and Weaver, D.: Investigation of $\mathrm{CO}, \mathrm{C}_{2} \mathrm{H}_{6}$ and aerosols in a boreal fire plume over eastern Canada during BORTAS 2011 using ground- and satellite-based observations and model simulations, Atmos. Chem. Phys., 13, 10227-10241, doi:10.5194/acp-13-10227-2013, 2013.

Herber, A.: Continuous day and night aerosol optical depth observations in the Arctic between 1991 and 1999, J. Geophys. Res., 107, 4097, doi:10.1029/2001JD000536, 2002.

Holben, B., Eck, T., Slutsker, I., Tanre, D., Buis, J., Setzer, A., Vermote, E., Reagan, J., Kaufman, Y. J., Nakajima, T., Lavenu, F., Jankowiak, I., and Smirnov, A.: AERONET - a federated instrument network and data archive for aerosol characterization, Remote Sens. Environ., 1-16, 1998.

Jacob, D. J., Crawford, J. H., Maring, H., Clarke, A. D., Dibb, J. E., Emmons, L. K., Ferrare, R. A., Hostetler, C. A., Russell, P. B., Singh, H. B., Thompson, A. M., Shaw, G. E., McCauley, E., Pederson, J. R., and Fisher, J. A.: The Arctic Research of the Composition of the Troposphere from Aircraft and Satellites (ARCTAS) mission: design, execution, and first results, Atmos. Chem. Phys., 10, 5191-5212, doi:10.5194/acp-10-5191-2010, 2010.
Jayne, J. T., Leard, D. C., Zhang, X., Davidovits, P., Smith, K. A., Kolb, C. E., and Worsnop, D. R.: Development of an aerosol mass spectrometer for size and composition analysis of submicron particles, Aerosol Sci. Tech., 33, 49-70, doi:10.1080/027868200410840, 2000.

Matsui, H., Kondo, Y., Moteki, N., Takegawa, N., Sahu, L. K., Zhao, Y., Fuelberg, H. E., Sessions, W. R., Diskin, G., Blake, D. R., Wisthaler, A., and Koike, M.: Seasonal variation of the transport of black carbon aerosol from the Asian continent to the Arctic during the ARCTAS aircraft campaign, J. Geophys. Res., 116, D05202, doi:10.1029/2010JD015067, 2011.

McMillan, W. W., Warner, J. X., Comer, M. M., Maddy, E., Chu, A., Sparling, L., Eloranta, E., Hoff, R., Sachse, G., Barnet, C., Razenkov, I., and Wolf, W.: AIRS views transport from 12 to 22 July 2004 Alaskan/Canadian fires: correlation of AIRS CO and MODIS AOD with forward trajectories and comparison of AIRS CO retrievals with DC-8 in situ measurements during INTEX-A/ICARTT, J. Geophys. Res., 113, D20301, doi:10.1029/2007JD009711, 2008.

Moteki, N., Kondo, Y., Oshima, N., Takegawa, N., Koike, M., Kita, K., Matsui, H., and Kajino, M.: Size dependence of wet removal of black carbon aerosols during transport from the boundary layer to the free troposphere, Geophys. Res. Lett., 39, L13802, doi:10.1029/2012GL052034, 2012.

O'Neill, N. T.: Spectral discrimination of coarse and fine mode optical depth, J. Geophys. Res., 108, 4559, doi:10.1029/2002JD002975, 2003.

Oshima, N., Kondo, Y., Moteki, N., Takegawa, N., Koike, M., Kita, K., Matsui, H., Kajino, M., Nakamura, H., Jung, J. S., and Kim, Y. J.: Wet removal of black carbon in Asian outflow: aerosol radiative forcing in East Asia (A-FORCE) aircraft campaign, J. Geophys. Res., 117, D03204, doi:10.1029/2011JD016552, 2012.

Palmer, P. I., Parrington, M., Lee, J. D., Lewis, A. C., Rickard, A. R., Bernath, P. F., Duck, T. J., Waugh, D. L., Tarasick, D. W., Andrews, S., Aruffo, E., Bailey, L. J., Barrett, E., Bauguitte, S. J.B., Curry, K. R., Di Carlo, P., Chisholm, L., Dan, L., Forster, G., Franklin, J. E., Gibson, M. D., Griffin, D., Helmig, D., Hopkins, J. R., Hopper, J. T., Jenkin, M. E., Kindred, D., Kliever, J., Le Breton, M., Matthiesen, S., Maurice, M., Moller, S., Moore, D. P., Oram, D. E., O’Shea, S. J., Owen, R. C., Pagniello, C. M. L. S., Pawson, S., Percival, C. J., Pierce, J. R., Punjabi, S., Purvis, R. M., Remedios, J. J., Rotermund, K. M., Sakamoto, K. M., da Silva, A. M., Strawbridge, K. B., Strong, K., Taylor, J., Trigwell, R., Tereszchuk, K. A., Walker, K. A., Weaver, D., Whaley, C., and Young, J. C.: Quantifying the impact of BOReal forest fires on Tropospheric oxidants over the Atlantic using Aircraft and Satellites (BORTAS) experiment: design, execution and science overview, Atmos. Chem. Phys., 13, 6239-6261, doi:10.5194/acp-13-6239-2013, 2013.

Pougatchev, N. S., Connor, B. J., and Rinsland, C. P.: Infrared measurements of the ozone vertical distribution above Kitt Peak, J. Geophys. Res., 100, 16689, doi:10.1029/95JD01296, 1995.

Pougatchev, N. S., Connor, B. J., Jones, N. B., and Rinsland, C. P.: Validation of ozone profile retrievals from infrared ground-based solar spectra, Geophys. Res. Lett., 23, 1637-1640, doi:10.1029/96GL01501, 1996.

Rodgers, C. D.: Retrieval of atmospheric temperature and composition from remote measurements of thermal radiation, Rev. Geophys., 14, 609, doi:10.1029/RG014i004p00609, 1976. 
Rodgers, C. D.: Inverse Methods for Atmospheric Sounding: Theory and Practice, World Scientific Publishing Company, Incorporated, Singapore, 2000.

Rolph, G.: Real-time Environmental Applications and Display sYstem (READY) Website http://ready.arl.noaa.gov (last access: 9 January 2014), NOAA Air Resources Laboratory, Silver Spring, MD, 2013.

Rothman, L. S., Brown, L. R., Auwera, J. V., Rothman, L., Gordon, I., Barbe, A., Benner, D., Bernath, P., Birk, M., Boudon, V., Brown, L., Campargue, A., Champion, J.-P., Chance, K., Coudert, L., Dana, V., Devi, V., Fally, S., Flaud, J.-M., Gamache, R., Goldman, A., Jacquemart, D., Kleiner, I., Lacome, N., Lafferty, W., Mandin, J.-Y., Massie, S., Mikhailenko, S., Miller, C., Moazzen-Ahmadi, N., Naumenko, O., Nikitin, A., Orphal, J., Perevalov, V., Perrin, A., Predoi-Cross, A., Rinsland, C., Rotger, M., Šimečková, M., Smith, M., Sung, K., Tashkun, S., Tennyson, J., Toth, R., Vandaele, A., and Vander Auwera, J.: The HITRAN 2008 molecular spectroscopic database, J. Quant. Spectrosc. Ra., 110, 533-572, 2009.
Seinfeld, J. H. and Pandis, S. N.: Atmospheric Chemistry and Physics, 2nd edn., John Wiley \& Sons, Inc., Hoboken, New Jersey, USA 2006.

Stohl, A., Forster, C., Frank, A., Seibert, P., and Wotawa, G.: Technical Note: The Lagrangian particle dispersion model FLEXPART version 6.2, Atmos. Chem. Phys., 5, 2461-2474, doi:10.5194/acp-5-2461-2005, 2005.

Taylor, J. W., Allan, J. D., Allen, G., Coe, H., Williams, P. I., Flynn, M. J., Le Breton, M., Muller, J. B. A., Percival, C. J., Oram, D., Forster, G., Lee, J. D., Rickard, A. R., and Palmer, P. I.: Size-dependent wet removal of black carbon in Canadian biomass burning plumes, Atmos. Chem. Phys. Discuss., 14, 19469-19513, doi:10.5194/acpd-14-19469-2014, 2014. 